NBER WORKING PAPER SERIES

\title{
THE CONTRIBUTION OF CHINESE FDI TO AFRICA'S PRE CRISIS GROWTH SURGE
}

\author{
Aaron Weisbrod \\ John Whalley \\ Working Paper 17544 \\ http://www.nber.org/papers/w17544
NATIONAL BUREAU OF ECONOMIC RESEARCH 1050 Massachusetts Avenue
Cambridge, MA 02138
October 2011

We are grateful to the Ontario Research Fund for financial support, and to Terry Sicular for discussions. The views expressed herein are those of the authors and do not necessarily reflect the views of the National Bureau of Economic Research.

NBER working papers are circulated for discussion and comment purposes. They have not been peerreviewed or been subject to the review by the NBER Board of Directors that accompanies official NBER publications.

(C) 2011 by Aaron Weisbrod and John Whalley. All rights reserved. Short sections of text, not to exceed two paragraphs, may be quoted without explicit permission provided that full credit, including (C notice, is given to the source. 
The Contribution of Chinese FDI to Africa's Pre Crisis Growth Surge

Aaron Weisbrod and John Whalley

NBER Working Paper No. 17544

October 2011

JEL No. F21,F43,O4,O47,O55

\begin{abstract}
In the 3 years before the 2008 Financial Crisis, GDP growth in sub Saharan Africa (averaged over individual economies) was around $6 \%$, or 2 percentage points above mean growth rates for the preceding 10 years. This period also coincided with significant Chinese FDI flows into these countries, accounting for up to $10 \%$ of total inward FDI flows for certain countries in these years. We use growth accounting methods to assess what portion of this elevated growth can be attributed to Chinese inward FDI. We follow Solow (1957), Dennison (1962), and others and use data for individual economies between 1990 and 2008 to calculate Solow residuals for these years for individual economies. We use capital stock data, workforce, and factor share data by country. Capital stock data is unavailable directly, and so we use perpetual inventory methods to construct the data. Factor shares come from UN National Accounts data. We then run counterfactual growth accounting experiments for thirteen Sub-Saharan African countries excluding Chinese FDI inflows for 2005-2007 and also 2003-2009. Our individual results vary by year and country, but there are several year/country combinations where Chinese FDI contributed to an additional one half of a percentage point or above to GDP growth. These results suggest that a significant, even if in some cases small, portion of the elevated growth in sub Saharan Africa in the three years before the Financial Crisis and also in the two years afterwards (2008-2009) can be attributed to Chinese inward investment.
\end{abstract}

Aaron Weisbrod

Department of Economics

The University of Western Ontario

London, Ontario N6A 5C2 CANADA

A.Weisbrod@lse.ac.uk

John Whalley

Department of Economics

Social Science Centre

University of Western Ontario

London, ON N6A 5C2

CANADA

and NBER

jwhalley@uwo.ca 


\section{Introduction}

In the 3 years before the 2008 Financial Crisis, GDP growth in sub Saharan Africa (averaged over individual economies) was around $6 \%$, or 2 percentage points above mean growth rates for the preceeding 10 years. This period also coincided with significant Chinese FDI flows into these countries, accounting for as high as $10 \%$ of inward FDI flows for some countries during these years. We use growth accounting methods to assess what portion of this elevated growth can be attributed to Chinese inward FDI.

Chinese FDI over this period was uneven in both country and sectoral coverage. It was heavily concentrated in a relatively small number of countries and also went heavily into resource sectors. The majority of this FDI was greenfield/new investment, with the notable exception of the purchase of a significant position in a major South African bank in 2008. Given the large number of African countries, our analysis focuses on the largest economies and the largest recipients of Chinese inward FDI. We consider a group which comprises 13 economies (these are: Angola, Botswana, the Democratic Republic of the Congo (DRC), Ethiopia, Ghana, Kenya, Madagascar, Niger, Nigeria, South Africa, Sudan, Tanzania, and Zambia) accounting for $78 \%$ of sub Saharan African GDP, and $92 \%$ of Chinese FDI flows between 2003 and 2009.

We follow Solow (1957), Dennison (1962), and others and use data for individual economies between 1990 and 2009 to first calculate Solow residuals for these years for individual economies. We use capital stock, workforce, and factor share data by country. Capital stock data is unavailable directly, and so we use perpetual inventory methods to construct the data. Factor shares come from UN National Accounts data or the World Bank Development Indicators depending on the calculation method (this is further addressed later in this text). 
We then use data on Chinese FDI inflows by country to decompose capital stock change estimates by country for the years $2003-2009^{1}$ into the portion due to Chinese inflows, and the remaining non Chinese FDI portion. Removing Chinese FDI driven capital stock change from the factor input data in the growth accounting enables us to assess what growth rates would have been without Chinese FDI.

We run counterfactual growth accounting experiments for our thirteen Sub-Saharan African countries both for the three years 2005-2007 and the longer period 2003-2009. Our estimates of Chinese FDI's contribution to the GDP growth varies by nation and year. There are years where GDP growth was elevated by upwards of one half of a percentage point due to inward Chinese FDI (most notably Zambia from 2006-2008 with $0.44-0.67 \%$ per annum, Niger in 2007 at $0.38 \%$, and the DRC in 2009 at $0.65 \%)$. Although for some countries and years, the effects were smaller or even negligible, some countries saw total GDP growth over the total period (ie the growth in GDP from 2002 to 2009) increase by 0.5 percentage points or higher due to inward Chinese FDI alone. The contribution of Chinese FDI to Sub-Saharan African growth also expanded from having significant growth effects in a relatively small group of core countries (Nigeria, Niger, Sudan, Zambia and to a lesser extent the DRC) in the years preceding the world financial crisis (2005-2007) to also producing noticeable, even if smaller, growth effects in a wider range of Sub-Saharan African countries during the years of the crisis (20082009). These results suggest that a significant, even if in some cases small, amount of the elevated growth in sub Saharan Africa in recent years can be attributed to Chinese inward investment.

Several caveats apply to both the data and the use of growth accounting techniques for this purpose. One is that exploration expenses in resource industries are largely expensed which tends to understate the investment estimates used to construct capital stock data in some key countries. Another is that factor share data in African National Accounts are typically based on wages paid and

\footnotetext{
${ }^{1}$ Although data for Chinese inward outward FDI is available for 2010, country-level data for our recipient countries only go up to 2009 so it is currently not possible for our experiments to include 2010.
} 
returns to smallholders fully show as capital in use. This use of share data upward biases the contribution of investment to growth in the growth accounting. Finally, ideally a clear separation is needed between greenfield Chinese investment and purchase of existing assets when using Chinese FDI data for our purposes (we discuss this issue in the text) we make some modifications to FDI data for this. Despite these caveats, our results are suggestive of a significant, even if in some cases small, contribution for Chinese FDI to elevated African growth; a feature which is likely even more pronounced post crisis since Chinese FDI into Africa has increased further. 


\section{African Growth and Chinese FDI}

The mid-to-late 2000's saw a period of elevated GDP growth in Sub-Saharan Africa. As Figure 1 indicates, from 1995 to 2002, GDP growth on the continent remained generally between 2 and 4\% per annum (with 1996 being the only exception at 5\%). There was, however, a significant rise in SubSaharan Africa's growth following this period, with annual GDP growth reaching $6.2 \%$ in 2004 and remaining above $5.5 \%$ until the onset of the 2008 Financial crisis when it declined to $5 \%$ in 2008 and fell further in 2009 to $1.7 \%{ }^{2}$ While this increase in GDP growth does coincide with an elevated rate of world GDP growth, the elevation in Sub-Saharan African growth is in excess of the World increase (see Figure 1). Undoubtedly, a portion of the increase in posted growth rates for many of the Sub-Saharan African nations are partially explained by the pre-financial crisis commodity boom. However, this increase in Sub-Saharan African growth rates also coincides with significant increases in Chinese inward foreign direct investment (FDI) over the years from 2003-2009. This period is marked by a rapid expansion in many aspects of China's presence in Africa, manifesting itself through heightened levels of Chinese aid, FDI and a deepening of diplomatic ties with many African countries.

Figure 1: Annual GDP growth for the World and Sub-Saharan Africa (\%)

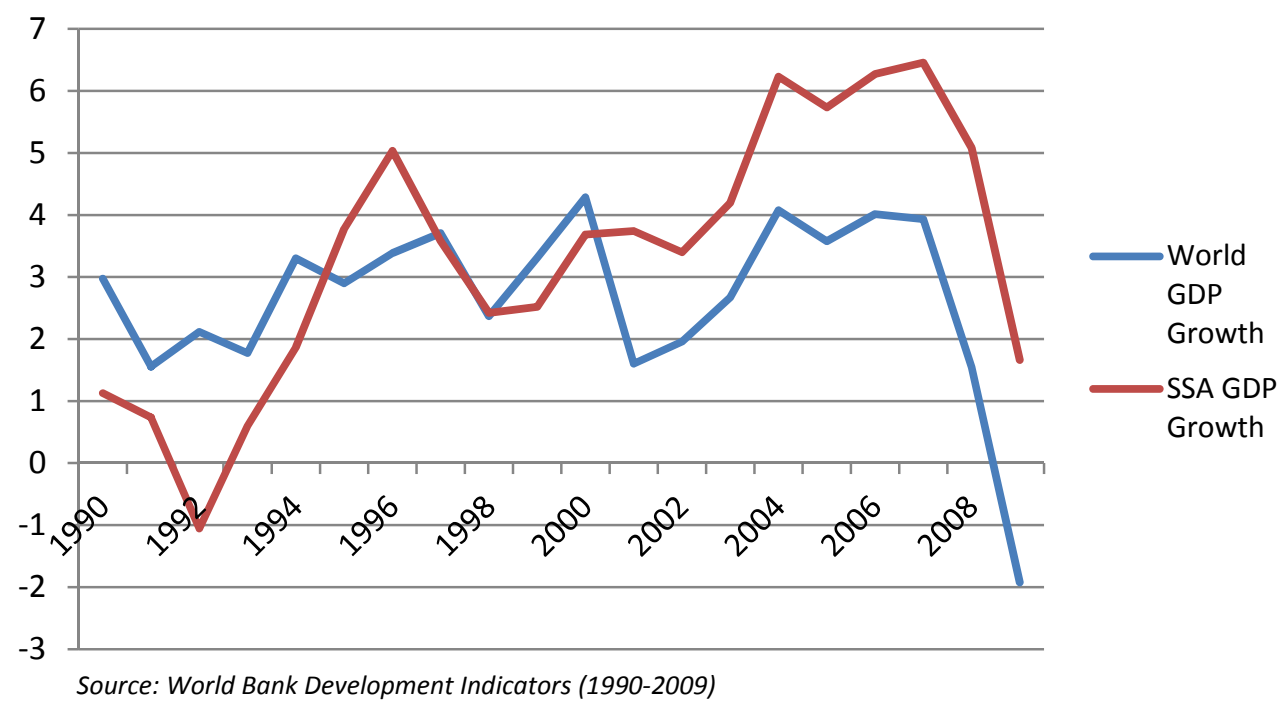

\footnotetext{
${ }^{2}$ Source: World Bank Development Indicators
} 
Chinese FDI inflows totaled \$US 64 million between 1979 and 2000. ${ }^{3}$ But as Table 1 indicates, this was surpassed in 2003 alone, when Chinese FDI amounted to \$US 70.14 million. By 2007, annual Chinese FDI into Sub-Saharan Africa was in excess of \$US 1 billion, remaining in the billions for both 2008 and 2009 and increasing to over \$US 2 billion in 2010. ${ }^{4}$ For some countries, Chinese FDI rose from virtually nil in 2003 to the hundreds of millions by $2009 .{ }^{5}$ Although this growth is from a small base, it is indicative of a shift in Sino-African relations, with China becoming increasingly involved in the continent. This change is also partially a reflection of a general increase in China's outward FDI flows worldwide, with these having increased from \$US 2.85 billion in 2003 to \$US 56.53 billion by 2009 (and on to \$US 68.8 billion in 2010), with China becoming the $5^{\text {th }}$ highest country for outward FDI globally. ${ }^{6}$

Between 1980 and 2009, Sub-Saharan Africa attracted no more than 2.05\% of total world FDI in any given year ${ }^{7}$, roughly in line with its size in the world economy, with Sub-Saharan Africa comprising between $1-2 \%$ of global GDP from $2003-2009 .{ }^{8}$ Chinese FDI flows into Sub-Saharan Africa, on the other hand, accounted for $5 \%$ of total Chinese FDI over the period of $2003-2009$, making up $9.7 \%$ of total Chinese FDI in 2008. ${ }^{9}$ Chinese FDI flows into Sub-Saharan Africa, although still a small portion of world FDI flowing into the continent, increased from $0.4 \%$ of total inward FDI in 2003 to $3.3 \%$ in 2007, and remained above $2.5 \%$ throughout $2008-2009 .{ }^{10}$ Chinese FDI has also been concentrated by country and

\footnotetext{
${ }^{3}$ United Nations Development Programme, Asian Foreign Direct Investment in Africa, 56.

${ }^{4}$ Ministry of Commerce, People's Republic of China, Statistical Bulletin of China's Outward Foreign Direct Investment, 2010. Beijing: People's Republic of China. 2010.

${ }^{5}$ Some examples are the Sudan (increasing from \$US 0.55 million to \$US 564 million), Tanzania (increasing from \$US 7.46 million to \$US 282 million), and Angola (increasing from \$US 0.30 million to \$US 196 million).

${ }^{6}$ MOFCOM Statistical Bulletin, 2010.

${ }^{7}$ Source: UNCTADstat, United Nations Conference for Trade and Development statistical database, http://unctadstat.unctad.org/ReportFolders/reportFolders.aspx?sCS_referer=\&sCS_ChosenLang=en

${ }^{8}$ Source: World Bank Development Indicators

${ }^{9}$ MOFCOM Statistical Bulletin, 2010

${ }^{10}$ It made up $10 \%$ of total world FDI in Sub-Saharan Africa for 2008. This is, however, largely centered around a one-time transaction in South Africa around China's ICBC purchasing a 20\% stake in South Africa's Standard Bank for \$US 5.5 billion.
} 
sector. In Zambia, for instance, between 2006 and 2009 it made up approximately $10 \%$ of total inward FDI. ${ }^{11}$

Table 1: Chinese FDI Inflows into Sub-Saharan Africa (SSA)

\begin{tabular}{|c|c|c|c|c|c|c|c|}
\hline Year & 2003 & 2004 & 2005 & 2006 & 2007 & $2008^{*}$ & 2009 \\
\hline $\begin{array}{c}\text { Total Chinese FDI Flows into } \\
\text { SSA (\$US millions) }\end{array}$ & 70.14 & 300.22 & 293.25 & 418.86 & 1361.49 & 5423.19 & 1161.1 \\
\hline $\begin{array}{c}\text { Total Chinese Outward } \\
\text { FDI (\$US millions) }\end{array}$ & 2854.65 & 5497.99 & 12261.17 & 17633.97 & 26506.09 & 55907.17 & 56528.99 \\
\hline $\begin{array}{c}\text { Chinese FDI Flows into SSA as } \\
\% \text { of } \\
\text { Total outwards Chinese FDI }\end{array}$ & $2.50 \%$ & $5.50 \%$ & $2.40 \%$ & $2.40 \%$ & $5.10 \%$ & $9.70 \%$ & $2.00 \%$ \\
\hline $\begin{array}{c}\text { Chinese FDI Flows into SSA as } \\
\text { a } \\
\% \text { of total FDI into SSA }\end{array}$ & $0.42 \%$ & $1.79 \%$ & $1.04 \%$ & $1.17 \%$ & $3.34 \%$ & $10.70 \%$ & $2.58 \%$ \\
\hline $\begin{array}{c}\text { SSA GDP as a \% of } \\
\text { world (excl. China) GDP }\end{array}$ & $1.25 \%$ & $1.39 \%$ & $1.51 \%$ & $1.63 \%$ & $1.68 \%$ & $1.78 \%$ & $1.80 \%$ \\
\hline $\begin{array}{c}\text { Annual growth in } \\
\text { Global FDI Flows to Africa }\end{array}$ & $-9.93 \%$ & $29.46 \%$ & $34.60 \%$ & $48.02 \%$ & $43.92 \%$ & $-15.67 \%$ & $-37.08 \%$ \\
\hline
\end{tabular}

Source: World FDI data come from the UNCTAD statistical database. GDP from the World Bank Indicators and Chinese FDI data are from MOFCOM statistics

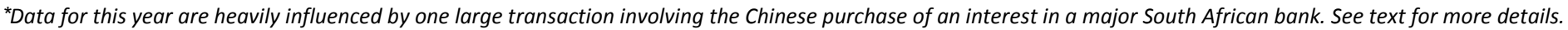

Chinese FDI (as well as aid) flows into Africa have been characterized by an emphasis on mutually beneficial commercial transactions, which is in contrast to much of the aid and investment from the West which is often contingent on standards of governance and transparency. This was summed up in the comment of Zhou Wenzhong, China's deputy foreign minister, that "business is business. We try to separate politics from business...You [the West] have tried to impose a market economy and multiparty democracy on these countries which are not ready for it" ${ }^{12}$ Chinese direct investments are driven by a variety of factors. For example, in West Africa it is primarily centered in oil, whereas in Southern Africa it is in predominantly metals and minerals. Chinese FDI has been more

\footnotetext{
${ }^{11}$ Source: Comparing MOFCOM statistical bulletin with UNCTAD Stat database; both in current \$US.

${ }^{12}$ French, Howard (2004) “China in Africa: All Trade and No Political Baggage," New York Times, August 8, 2004.
} 
significant in African countries less renowned for their standards of governance, such as the Democratic Republic of the Congo and the Sudan.

Chinese FDI has also been heavily targeted at facilitating and expanding resource extraction. China's economy has been growing rapidly over the last three decades and China now seeks new sources of natural resources in order to sustain its growth. The African continent contains large reserves of many natural resources, with upwards of $60 \%$ of the global Platinum Group Metal reserves, $55 \%$ of global cobalt reserves, and $45 \%$ of global aluminum reserves. Also, as Kaplinsky \& Morris (2009) points out, Africa as a whole is also poorly prospected, so it is also likely that the true shares of many of these resources are in reality significantly higher. ${ }^{13}$

Several countries also receive Chinese FDI in their manufacturing sectors, as a result of "quotahopping" foreign investment. Due to the terms of China's accession to the World Trade Organization (WTO) in 2001, China is still classified as a "non-market economy."14 This designation, coupled with the other terms of China's terms of WTO accession, allows other countries to impose trade sanctions and quotas against China in order to combat perceived import surges. These sanctions predominantly consist of product-specific annual growth rate quotas and increased latitude for imposing anti-dumping and countervailing duties. ${ }^{15}$ As such, increases in the number of these measures being imposed have led Chinese firms to seek ways to circumvent them by relocating production elsewhere. By relocating production to Africa, Chinese firms can avoid China-specific trade sanctions as well as take advantage of many preferential trade agreements involving African countries such as the African Growth and

\footnotetext{
${ }^{13}$ Kaplinsky, Robert and Mike Morris, "Chinese FDI in Sub Saharan Africa: Engaging With Large Dragons," European Journal of Development Research 21 (2009), 11.

${ }^{14}$ OG Dayaratna-Banda and John Whalley, "After the MFA, the CCAs," Working Paper 24 (The Center for International Governance Innovation, 2007), 9.

${ }^{15}$ Dayaratna-Banda and Whalley, "After the MFA, the CCAs," 2, 9.
} 
Opportunity Act. ${ }^{16}$ This is apparent in that significant Chinese investments are taking place in textiles, specifically garments and shoes. ${ }^{17}$

There is also a political component to Chinese FDI inflows into Africa. In the wake of the 2006 Beijing Summit on China-Africa cooperation, the Chinese government pledged further aid as well as commitments to promote Chinese investment in the African continent. In response to this summit, the Chinese government established the China-Africa Development Fund (CAD Fund). With initial funding of US\$1 billion and a pledge of eventual expansion to US\$5 billion, the CAD Fund has the goal of promoting Chinese investment in Africa. ${ }^{18}$ The CAD Fund has become a significant tool for promoting Chinese FDI in African nations. The fund itself was responsible for over 30\% of China's investments in Africa in 2009 either through its own direct capital or facilitating other Chinese firms' capital. ${ }^{19}$ Besides the CAD Fund, China has also established a range of different incentives which encourage investment in Africa by Chinese firms. For example, companies investing in Africa gain access to prioritized credit at lower interest rates as well as tax incentives and other benefits. Thus, through the use of many different tools (such as incentive structures for Chinese firms and the CAD Fund), the Chinese government continues to encourage Chinese firms to invest in Africa.

\footnotetext{
${ }^{16}$ African Growth and Opportunity Act Website - http://www.agoa.gov/agoalegislation/index.asp

${ }^{17}$ Kaplinsky and Morris, "Chinese FDI in Sub Saharan Africa: Engaging With Large Dragons,", 7.

${ }^{18}$ CAD Fund website - http://www.cdb.com.cn/english/Column.asp?Columnld=176 (accessed Aug 30 ${ }^{\text {th }}, 2011$ )

${ }^{19}$ Zhou Yan. "CAD Fund to boost footprint in Africa."
} 


\section{Methodology for Assessing China FDI's impact on African Growth}

\subsection{Solow Growth Accounting}

Assessing the contribution of Chinese FDI to Sub-Saharan African GDP growth involves separating GDP growth into its respective sources. Solow growth accounting separates output growth into changes in individual productive inputs (such as labor and capital) and productivity (which determines how efficiently inputs are used). Utilizing Solow's (1957) growth accounting approach, it is thus possible to divide changes in output into the contributions from its respective inputs (i.e. labor and capital) and total factor productivity (Solow, 1957). We also use this approach to assess the contribution of Chinese FDI inflows to growth in the larger African economies.

Solow's original experiment was to determine the sources of economic growth in the United States between 1870 and 1949 . Solow came to the conclusion that over the test period, $87.5 \%$ of the growth in the United States could be attributed to technical progress, or increases in the Solow residual. Even though this assertion has been disputed since, Solow's growth accounting formula is still widely used when dealing with sources of economic growth.

Solow growth accounting begins with an aggregate production function for output $(\mathrm{Y})$, with output produced by a combination of inputs labor ( $L$ ) and capital (K) as well as total factor productivity (TFP) embodied in the Solow Residual (A) given by:

$$
Y_{t}=A_{t} f\left(K_{t}, L_{t}\right)
$$

As in Solow (1957), taking total derivatives leads to the Solow growth accounting equation:

$$
\frac{\dot{Y}}{Y}=\frac{\dot{A}}{A}+\frac{a \dot{K}}{K}+(1-a) \underline{\dot{L}}
$$

In this, $(\dot{Y})$ is equal to the change in output, $(\dot{\mathrm{A}})$ is equal to the change in TFP, and $(\dot{K})$ and $(\dot{L})$ for labor and capital. Given marginal product factor pricing the share of capital is $(\alpha)$ and under constant returns to scale the share of labor is equal to $(1-\alpha)$. This implies the percentage change in output is the 
percentage change in the Solow Residual plus the percentage changes in each of the capital stock and labor inputs multiplied by their respective shares.

Using estimates of labor force, GDP and capital stock growth, coupled with shares of labor and capital we can to determine the contributions to growth of each of the inputs and the Solow Residual. The Solow residual is calculated once data on all the other variables are gathered as follows:

$$
\frac{\dot{A}}{A}=\frac{\dot{Y}}{Y}-\frac{\alpha \underline{K}}{K}-(1-\alpha) \underline{\dot{L}}
$$

Using Solow growth accounting, one can also change the measure of capital inputs for African countries excluding FDI inflows from China, producing an output growth estimate for the same year excluding the influence of Chinese FDI. But first it is necessary to produce estimates of the total capital stock in each year before removing these capital flows. In the absence of capital stock data, it is common in the literature to use a perpetual inventory method to yield capital stock estimates. ${ }^{20}$ Under this approach, capital stock estimates for each year can be derived since the capital stock in a given period $\left(\mathrm{K}_{\mathrm{t}}\right)$ is equal to the sum of investment in that period $\left(\mathrm{I}_{\mathrm{t}}\right)$ and the previous period's capital stock $\left(\mathrm{k}_{\mathrm{t}-1}\right)$ multiplied by $(1-\delta)$ where $\delta$ is the depreciation rate:

$$
K_{t}=I_{t}+(1-\delta) K_{t-1}
$$

Taking investment data going back far enough and using a depreciation rate, it is possible to produce estimates of the capital stock for a given year or set of years for each of the African economies we analyze.

\subsection{Adjusting for the Quality of Inputs}

Solow's (1957) initial findings for the size of TFP's contribution to U.S. GDP growth were challenged by later studies which relaxed the assumptions that all capital and labor inputs are homogenous and instead made adjustments for quality change in inputs. Dennison (1962), in particular,

\footnotetext{
${ }^{20}$ See Bosworth et al. (1995), Bosworth \& Collins (2003), Sacerdoti et al. (1998), Berthelemy \& Soderling (2001), Bogetić et al. (2007) for a few examples.
} 
undertook an extensive growth accounting exercise within which he allowed for changes in the quality of the inputs, focusing particularly on the quality of the labor force. He decomposed sources of growth into changes in the levels of education, changes in average hours of work, and female participation and was able to produce estimates for each elements' individual contribution to growth in the United States from 1909-1957. Adding measures of quality change in productive inputs, he was able to transfer some of the portion of national income growth attributed to technological change instead to increases in labor force quality (via education). Jorgenson \& Griliches (1967) then improved upon Denison's methods further by further differentiating changes in the quality of the labor force and also adding in measures of changes in quality of the capital stock by disaggregating the capital stock and calculating real input prices for each of several investment goods. After many adjustments for changes in the quality of the productive inputs, Jorgenson \& Griliches (1967) were able to reduce the contribution of TFP to total growth to below $4 \%$ of total growth (or $0.10 \%$ per annum). Other later studies, such as Maddison (1987), continued to experiment with augmenting both labor and capital stocks with quality measures.

Education embodied in human capital has also been treated as an input in its own right in many growth accounting exercises. Barro and Lee (1993) have developed a method (and coinciding data) for many countries for producing human capital proxies, using average years of schooling based also on a perpetual inventory method. Due to the limited breadth and quality of data available for the individual African countries we analyze, it is not possible for us to perform a similar disaggregation of capital stocks data by country. Additionally, due to insufficient education data within some of the countries included in this study, it is also not possible for us to produce estimates of human capital, which results in human capital not being taken into account in this experiment. Since we are primarily interested in capital growth for the purposes of our experiments, this does not greatly affect our final results as both the labor input and TFP growth are held constant throughout our counterfactual experiments (as set out later in the paper). Additionally, we assume that all productive capital is homogeneous and that the 
discounted service value of capital is equal to the value of capital stock. This also applies to Chinese FDI as a source of capital to these African countries, and we operate under the assumption that Chinese FDI and other foreign FDI are homogeneous domestic capital.

\subsection{Counterfactual Experiments}

In analyzing the impact of Chinese FDI inflows on individual African country growth, we make initial growth accounting calculations to determine the Solow residual for each country. We then use these estimates to determine the magnitude of output growth of individual African countries that can be attributed to everything except Chinese inward FDI. We hold fixed the growth in TFP and labor force from the initial growth accounting experiment, then divide investment in each period (2003-2009) into the portion that is attributable to Chinese FDI and the rest. With the lower levels of investment in the absence of Chinese FDI, we redo the perpetual inventory method calculations to produce new counterfactual capital stock estimates. We then make new growth accounting calculations using the TFP and labor force growth rates from our initial experiment along with the growth rates in counterfactual capital stocks. Starting with our initial year in our counterfactual experiments, we carry our analysis through test years with the new capital stocks. This produces estimates of what GDP growth would have been in individual countries in the absence of Chinese FDI during the 2005-2007 and 2003-2009 periods.

Chinese FDI inflows are largely centered in manufacturing, resource extraction, and infrastructure development (particularly telecoms, power and transportation infrastructure). ${ }^{21}$ Most of this direct investment involves new capital that is used in production, but some is purchase of existing capital via portfolio investment. This raises the issue of dividing Chinese FDI into new and old capital investment. New investments add to the capital stock and increase output, whereas purchases of old capital only transfer ownership and do not create any new capital for production and, therefore, should

\footnotetext{
${ }^{21}$ Kaplinsky and Morris, “Chinese FDI in Sub Saharan Africa: Engaging With Large Dragons,”, 7.
} 
not be treated as adding to growth. With Chinese FDI inflows to African economies in which capital markets are limited, acquisitions of old capital are likely only a small part of Chinese FDI. There is, however, one large transaction in 2008 that requires special treatment. In 2008, the Industrial and Commercial Bank of China (ICBC) bought a $20 \%$ stake in South Africa's Standard Bank, valued at $\$ 5.5$ billion. $^{22}$ The Chinese Ministry of Commerce's data on outward FDI, show recorded levels of Chinese FDI into South Africa as approximately $\$ 4.8$ billion for 2008 , which is over ten times the flow into South Africa in 2007 and over a hundred times the flow in 2009. This is roughly equal to all other Chinese FDI flows into Africa between 2003 and 2009. Not only is this a large transaction, it is an investment in old capital, and this coupled with the magnitude of the transaction explains our exclusion of data South Africa for 2008 from our analysis. In the absence of disaggregated 2008 Chinese FDI data for South Africa, we set Chinese FDI into South Africa to zero in 2008.

Chinese FDI on the African continent, as a result of incentives used to promote Chinese investment in Africa, is also often bundled with various forms of Chinese aid and some of China's commercial involvement with Africa does not come in the form of only FDI. ${ }^{23}$ An example is in 2007, when China extended a \$US 2 billion loan to Angola while in the same year, data show Angola only received \$US 41 million of inward Chinese FDI. ${ }^{24}$ We make no adjustments to Chinese FDI data for these arrangements.

\footnotetext{
22 Mail \& Guardian Online. “China Approves ICBC Stake in Standard Bank." February $4^{\text {th }}, 2008$. http://mg.co.za/article/2008-02-04-china-approves-icbc-stake-in-standard-bank (accessed June 20th, 2011)

${ }^{23}$ Kaplinsky and Morris, "Chinese FDI in Sub Saharan Africa: Engaging With Large Dragons,", 14.

${ }^{24}$ Mohan, Giles and Marcus Power, "Africa, China and the 'new' economic geography of development," Singapore Journal of Tropical Geography, 30 (2009), 4.
} 


\section{Data}

\subsection{Perpetual Inventory Estimates of Country Capital Stock}

In our perpetual inventory calculation of capital stock data we use a geometric depreciation rate of $5 \%$. In growth accounting literature this is a common assumption, ${ }^{25}$ and geometric depreciation is also a common choice for a depreciation formula. Structures can often have service lives of between 50 and 80 years, whereas other capital goods, such as machinery and electronics, can have service lives of less than 10 years. ${ }^{26}$ When aggregated into a single capital stock, depreciation will occur more quickly as a whole at first as the assets with shorter service lives depreciate more quickly.

For the purposes of our perpetual inventory calculations, we use national Gross Fixed Capital Formation as investment in each period. Our data come from the United Nations Main Aggregates Database and are available for the years 1970-2009. ${ }^{27}$ This provides investment data which, when coupled with the depreciation rate, allow for the calculation of capital stock estimates via the perpetual inventory method. We also calculate an initial capital stock estimate for each country for 1970 using average GDP to capital stock ratios. ${ }^{28}$ Table 2 presents our estimates of 2003 capital stocks and their 2003 ratios of capital stocks to GDP.

\footnotetext{
${ }^{25}$ Senhadji (2000), Bosworth et al. (1995), and Nehru \& Dhareshwar (1993) are examples of papers using 4\%. Bosworth \& Collins (2003), Sacerdoti et al. (1998), Berthelemy \& Soderling (2001) are examples of papers using $5 \%$ ${ }^{26}$ See the OECD Manual for estimating capital stock data.

${ }^{27}$ UN Statistical Database - http://unstats.un.org/unsd/snaama/cList.asp

${ }^{28}$ For more discussion on the data and perpetual inventory method, see later in this section.
} 
Table 2: Capital Stock Estimates \& Capital Stock: GDP Ratios for Each Nation

\begin{tabular}{|c|c|c|c|c|c|}
\hline Country & $\begin{array}{c}2003 \text { Capital Stock } \\
\text { Estimate (\$US bill) }\end{array}$ & $\begin{array}{c}2003 \text { Capital Stock: } \\
\text { GDP Ratio }\end{array}$ & Country & $\begin{array}{c}2003 \text { Capital Stock } \\
\text { Estimate (\$US bill) }\end{array}$ & $\begin{array}{c}2003 \text { Capital Stock: } \\
\text { GDP Ratio }\end{array}$ \\
\hline Angola & $\$ 29$ & 2.01 & Niger & $\$ 7$ & 2.55 \\
Botswana & $\$ 22$ & 2.31 & Nigeria & $\$ 49$ & 0.61 \\
DRC & $\$ 19$ & 3.10 & South Africa & $\$ 436$ & 1.94 \\
Ethiopia & $\$ 26$ & 2.78 & Sudan & $\$ 27$ & 0.86 \\
Kenya & $\$ 33$ & 2.02 & Tanzania & $\$ 27$ & 2.24 \\
Ghana & $\$ 17$ & 1.87 & Zambia & $\$ 8$ & 1.31 \\
Madagascar & $\$ 10$ & 2.24 & & \\
\hline
\end{tabular}

Source: Capital Stock data is from authors calculations. GDP and Gross Fixed Capital Formation is from United Nations Income Accounts

\subsection{Output and Factor Share Data}

Our GDP data, which are our chosen measure of output, also come from the United Nations National Accounts Aggregates Database. Additionally, our labor force statistics are taken from the World Bank Development Indicators. Both provide full data on all of the countries from 2000-2009. ${ }^{29}$ Both the GDP and gross fixed capital formation statistics are denoted in constant \$US 2005 prices. This removes the need for any deflator in the growth accounting exercise as the GDP and capital stock/flow data are already denoted in common, constant prices. Since Chinese FDI statistics are denoted in current \$US prices, they have been deflated to 2005 prices using the IMF deflator index for the United States. ${ }^{30}$

Once the perpetual inventory method has been used to produce capital stock estimates, we then calculate estimates of the capital shares $(\alpha)$ and, by extension, labor shares. Since this is not often explicitly measured, it is still common practice to use profits divided by national income as a proxy for capital shares. ${ }^{31}$ In order to use profits as a share of GDP (for capital share) or total compensation as a

\footnotetext{
${ }^{29}$ More discussion on the labor force and GDP data, appears later in this section.

${ }^{30}$ International Monetary Fund, World Economic Outlook Data, http://www.econstats.com/weo/CUSA.htm

31 Nicholas Crafts, Solow and Growth Accounting: A Perspective from Quantitative Economic History, Paper for
} 
share of GDP (for labor share) as proxies, we make the assumption that the social marginal product of labor (or capital) is equal to the observed factor price. Under this assumption, we use gross operating surplus divided by output from the United Nations National Income Accounts as a proxy for ( $\alpha$ ) where available. We assume that the gross operating surplus is representative of total income accruing from capital. Gross operating surplus is defined by the UN National Income Accounts as the "surplus or deficit accruing from production before taking into account rent, interest or similar charges payable on financial or tangible non-produced assets...". ${ }^{32}$ Since gross operating surplus is essentially national income minus compensation paid, when divided by national income, it yields one minus the labor share, which given constant returns to scale, is the capital share.

Some of the countries we consider do not have this data available and in these cases, we use "compensation as a percent of expenses" as a proxy for the labor share (1- $\alpha)$. This produces capital shares that are similar to those using gross operating surplus divided by national income. Due to data limitations, it is also sometimes difficult to obtain data on compensation over national income and when available it generally produces labor shares of less than 0.1 . This is due to the feature that in poorer, predominantly agrarian economies, much of the income of the population is not monetarized as compensation due to subsistence farming or similar activities. Using compensation as a percent of expenses thus provides a lower bound of the true labor share.

Angola is a special case as data is not available to construct either of these proxies. Thus we take share data from Namibia (the country directly to its south). We assume that its values for the capital shares act as a reasonable representation of Angola's capital shares from 2003-2009. The mean values of capital shares by country over the period 2003-2009 are given in Table 3. Gollin (2002) also notes on errors in measurement of capital shares since the income of self-employed is often attributed entirely as capital income.

HOPE Conference at Duke University, Durham NC, April 2008

32 UN Statistical Division, National Accounts Statistics, 2006 Part I, pg. XXV. 
Additionally, in the case of certain countries, the data was unavailable for most of or all of the 2003-2009 period. In the cases where a few of the years were missing, an average of the available 20032009 years was used in their place. ${ }^{33}$ If all or nearly all of the 2003-2009 years were missing, an average of the values for the available previous years (i.e. 1990-2002) was used in their place. ${ }^{34}$

Table 3: Average Capital Shares 2003-2009 By Country by Calculation Technique

\begin{tabular}{|c|c|c|c|c|c|}
\hline \multicolumn{2}{|c|}{ Method GOS/GDP } & \multicolumn{2}{c|}{ Compensation (\% expenses) } & \multicolumn{2}{c|}{ By Proxy } \\
\hline Country & $\alpha$ & Country & $\alpha$ & Country & $\alpha$ \\
\hline Botswana & 0.44 & DRC & 0.65 & Angola & 0.31 \\
Kenya & 0.53 & Ethiopia & 0.68 & & \\
Niger & 0.35 & Ghana & 0.61 & & \\
Nigeria & 0.76 & Madagascar & 0.57 & & \\
South Africa & 0.45 & Zambia & 0.62 & & \\
Sudan & 0.73 & & & & \\
Tanzania & 0.79 & & & & \\
\hline
\end{tabular}

Source: Authors' Calculations

\subsection{Labour Data}

Labor force data for all 13 African countries are taken from the World Bank Development Indicators database. ${ }^{35}$ The series used is Labor Force, Total, which is people age 15 and older who meet the ILO criterion of being part of the economically active population. ${ }^{36}$ This data is from 2000 to 2009. Total labor force is used to represent labor input in production. We assume that average hours per worker remains constant over time.

\footnotetext{
${ }^{33}$ These countries included Zambia, Sudan, Nigeria, Madagascar, and Tanzania

${ }^{34}$ These countries included Ethiopia, the DRC, and Botswana

${ }^{35}$ Available at: http://databank.worldbank.org/ddp/home.do

${ }^{36}$ Definition taken from: http://data.worldbank.org/indicator/SL.TLF.TOTL.IN
} 


\subsection{GDP}

GDP data for all 13 African countries are taken from the UN National Accounts Main Aggregates Database. ${ }^{37}$ GDP data are available from 1970 to 2009, and is recorded in US dollars at constant 2005 prices. In this database, the Federal Democratic Republic of Ethiopia is divided into Former Ethiopia (1970-1993) and Ethiopia (1990-2009). The latter is used in this paper.

\subsection{Gross Fixed Capital Formation (GFCF) Data}

In applying perpetual inventory method used in this paper, gross fixed capital formation represents yearly investment in the country capital stock. Net Capital Formation is unavailable for most of the countries we include. GFCF is commonly used in the estimation of capital stocks as a good proxy of investment, ${ }^{38}$ and are also taken from the United Nations National Accounts Main Aggregates Database. $^{39}$ This data is likewise available from 1970-2009 and denoted in US dollars at constant 2005 prices. In the Ethiopia case, GFCF data for 1970 to 1989 are taken from the Former Ethiopia accounts and data for 1990 to 2009 from the "Ethiopia" accounts.

\subsection{Chinese Foreign Direct Investment (FDI)}

Data on Chinese outward FDI flows are taken from the Chinese Ministry of Commerce's (MOFCOM) 2010 Statistical Bulletin of China's Outward Foreign Direct Investment. ${ }^{40}$ This gives data on both Chinese outward FDI stocks and flows by receiving region or country from 2003 to 2009 . All data is denoted in current \$US, and these data are deflated to their 2005 levels when used in our counterfactual experiments.

\footnotetext{
${ }^{37}$ UN Statistical Database - http://unstats.un.org/unsd/snaama/selCountry.asp

${ }^{38}$ Yan \& Yao (2003), Bosworth \& Collins (2007), and Hofman (1992) are a few examples.

${ }^{39}$ UN Statistical Database - http://unstats.un.org/unsd/snaama/selCountry.asp

${ }^{40}$ Available Online at:

http://english.mofcom.gov.cn/aarticle/statistic/foreigninvestment/201109/20110907742320.html
} 


\subsection{Initial Capital Stocks $\left(\mathrm{K}_{0}\right)$}

Following Nehru \& Dhareshwar (1993), initial capital stock estimates for 1970 are generated by first obtaining capital stock estimates for 2003-2009 assuming that the initial capital stock was zero. We then calculated the 2003-2009 capital stock to GDP ratios and then apply the average of the ratios of these years to 1970 GDP by country to get an approximation to the initial (1970) capital stock. 


\section{Results}

\subsection{Overall Results}

Inflows of Chinese FDI into Sub-Saharan Africa have in some cases had significant effects on the GDP growth rates in some countries and have had a negligible effect in others. Table 4 reports the contribution of Chinese FDI to the GDP growth of select African countries over the 2005-2007 period.

Table 4: GDP growth attributable to Chinese FDI (2005-2007)*

\begin{tabular}{|c|c|c|c|}
\hline Country & $\begin{array}{c}\text { Percentage Points } \\
\text { of GDP Growth } \\
\text { from } \\
\text { Chinese FDI }\end{array}$ & Country & $\begin{array}{c}\text { Percentage Points } \\
\text { of GDP Growth } \\
\text { from } \\
\text { Chinese FDI }\end{array}$ \\
\hline Angola & $0.06 \%$ & Niger & $0.4 \%$ \\
Botswana & $0.01 \%$ & Nigeria & $0.6 \%$ \\
DRC & $0.3 \%$ & South Africa & $0.05 \%$ \\
Ethiopia & $0.08 \%$ & Sudan (whole) & $0.54 \%$ \\
Ghana & $0.01 \%$ & Tanzania & $0.02 \%$ \\
Kenya & $0.01 \%$ & Zambia & $1.01 \%$ \\
Madagascar & $0.06 \%$ & & \\
Source: Author's Calculations. \\
*For Sudan, 2004 is also included in the calculations; see text for explanation
\end{tabular}

During pre-crisis period, Chinese FDI in Africa is more concentrated by country than over the whole 2003-2009 period. In these years, Niger, Nigeria, Sudan, and Zambia saw additional GDP growth relative their $2005-2007$ rates of at least 0.4 percentage points due to Chinese inward FDI.

Table 5 presents our findings for the longer period 2003-2009. Generally, with the exception of Zambia (which saw 1.9\% GDP growth over the 2003-2009 period originating from Chinese FDI), percentage points of annual growth rates attributable to Chinese FDI over the 2003-2009 period are within the range of $0.04 \%-1.0 \%$. These results suggest that Chinese FDI over the period from 2003-2009 lead to an increase on the 2002 levels of GDP of between $0.04 \%$ and $1.9 \%$ (depending on the country) relative to GDP at the end of 2009. 
Table 5: GDP growth attributable to Chinese FDI (2003-2009)

\begin{tabular}{|c|c|c|c|}
\hline Country & $\begin{array}{c}\text { Percentage Points } \\
\text { of GDP Growth } \\
\text { from } \\
\text { Chinese FDI }\end{array}$ & Country & $\begin{array}{c}\text { Percentage Points } \\
\text { of GDP Growth } \\
\text { from } \\
\text { Chinese FDI }\end{array}$ \\
\hline Angola & $0.04 \%$ & Niger & $0.5 \%$ \\
Botswana & $0.05 \%$ & Nigeria & $0.9 \%$ \\
DRC & $1.0 \%$ & South Africa & $0.04 \%$ \\
Ethiopia & $0.2 \%$ & Sudan & $0.3 \%$ \\
Ghana & $0.1 \%$ & Tanzania & $0.1 \%$ \\
Kenya & $0.07 \%$ & Zambia & $1.9 \%$ \\
Madagascar & $0.5 \%$ & & \\
\hline
\end{tabular}

Source: Author's Calculations.

Some countries that showed moderate, but noticeable, improvements in GDP growth as a result of inward Chinese FDI over the whole 2003-2009 period saw declines in the effects of Chinese FDI when the scope was restricted to only $2005-2007 .^{41}$ Additionally, countries which initially saw negligible effects of inward Chinese FDI on their GDP growth (such as Angola and Botswana) remained largely the same or saw further declines in the contributions of Chinese FDI to their growth.

With the exception of Sudan in 2004 (which received almost half of total 2004 Chinese FDI into Africa $\$ 147$ million US) ${ }^{42}$, Chinese FDI into individual African countries in 2003-2004 was generally small. As a result, most of the difference between 2005-2007 and 2003-2009 results originates from increases in Chinese FDI in the 2008-2009 period. Chinese FDI remained strong in the pre-crisis period in a core group of countries (primarily Nigeria and Zambia, but also Niger and the DRC to a lesser extent). In the years of 2008-2009, Chinese FDI flows continue to be strong into these core countries and in some cases increased. Additionally, other countries in Sub-Saharan Africa start to see increased inward FDI flows from China during this period and show large increases in recorded contributions of Chinese FDI to GDP

\footnotetext{
${ }^{41}$ Ghana saw a drop from $0.1 \%$ to $0.01 \%$, Ethiopia from $0.2 \%$ to $0.08 \%$, The DRC from $1.0 \%$ to $0.3 \%$ and Tanzania from $0.1 \%$ to $0.02 \%$.

${ }^{42}$ Leaving out 2004 data for Sudan would seriously understate Chinese FDI's contribution to pre-crisis growth in Sudan's case.
} 
growth over the 2008-2009 period. Those nations (specifically Tanzania, Ethiopia, Ghana, and to a lesser extent Kenya) which see negligible effects of Chinese FDI on GDP growth initially show their effects as increasing significantly in the last few years. Another large jump occurs for the DRC which sees the Chinese FDI's contribution to GDP growth increase from $0.3 \%$ to $1.0 \%$ when the time period is enlarged to include 2009, when it received the majority of its Chinese FDI.

In East Africa, which up until 2008 saw relatively little inward Chinese FDI, in the cases of Tanzania, Kenya, and Ethiopia, Chinese annual FDI increased significantly in the 2008-2009 period. ${ }^{43}$ Flows into these countries still remain small when compared to inward Chinese FDI into the more core recipient countries, but flows into the more periphery recipients have increased significantly in the last few years and is reflected in the elevated contributions of Chinese FDI to these nations growth in the 2008-2009 period. Chinese total outward FDI increased by over 100\% from 2007 to 2008 (from US\$ 26.5 billion to US\$ 55.9 billion) and is partially responsible for the increases in Chinese FDI into the African continent. While Chinese FDI continues to remain strong in their core countries, China has increased in its outward direct investment into a wider range of Sub-Saharan African countries. This suggests that in addition to an increase in Chinese FDI's contributions to GDP growth in the core countries within which it now invests heavily, it is also likely that we will see increases in the breadth of Sub-Saharan African countries in the future. This trend continues according to the posted 2010 FDI flows which show especially large Chinese FDI inflows into the DRC, Ethiopia, Ghana, Kenya, Niger, Nigeria and Zambia.

While the country results may seem small, closer inspections of the results does reveal that, by country and sector, Chinese FDI is, in many cases, highly clustered in certain years. As a result, Chinese FDI may have had a relatively small impact on growth in the whole 2003 to 2009 period, but more concentrated impacts in individual years. Table 6 summarizes these years. For many cases, near all of

\footnotetext{
${ }^{43}$ Ethiopia saw an inflow of US $\$ 74.29$ million in 2009 versus and average of US\$ 8.8 million annually in 2003-2008. Kenya averaged US\$25.68 million annually in 2008-2009 versus an average of US\$2.91 million annually in 20032007. Tanzania averaged US\$19.9 million annually in 2008-2009 versus US\$2.26 million annually in 2003-2007.
} 
the growth originating from Chinese FDI resulted in two or three years as opposed to the whole seven. For some countries such as Ethiopia or Ghana, Chinese FDI's contribution to the 2003-2009 GDP growth came predominantly from a single year. For example, Nigeria's experience is that GDP grew $0.7 \%$ as a result of Chinese GDP between 2007 to 2009 (whereas it grew 0.9\% from 2003 to 2009).

Taking into account the recent growth in Chinese FDI into Africa and the small base that it started from in 2003, the ability of Chinese FDI to have, in some cases significant effects on GDP growth in certain countries is notable. As Table 6 indicates, there are several years, where Chinese FDI had significant effects (in the range $0.1-0.7 \%$ GDP growth) on individual country growth rates.

Although Chinese FDI's growth contributions are not dominant, the potential is for increased contributions to African growth in the future. With the exception of Sudan, the largest growth effects are in the period 2007 to 2009 . This is likely as a result of increased prospecting and drilling/mining activity. For example, Namibia has discovered oil reserves that may be in excess of 11 billion barrels. ${ }^{44}$ With threats of trade sanctions on Chinese exporting firms are unlikely to go away, especially with increased trade links to climate change, it seems likely to us that we will see China continue to take an increased interest in Africa and increase further its FDI flows into the region.

\footnotetext{
${ }^{44}$ Njini, Felix, “Namibia: The Next Oil Frontier." Southern Times, July $8^{\text {th }}, 2011$, http://www.southerntimesafrica.com/article.php?title=Namibia\%3A_the_next_oil_frontier\&id=6097 (accessed July $\left.9^{\text {th }}, 2011\right)$
} 
Table 6: Years of Note for Chinese FDI's effects on GDP Growth

\begin{tabular}{|cc|c|cc|c|}
\hline Country & Year & $\begin{array}{c}\text { GDP Growth from } \\
\text { Chinese FDI }\end{array}$ & Country & Year & $\begin{array}{c}\text { GDP Growth from } \\
\text { Chinese FDI }\end{array}$ \\
\hline DRC & 2009 & $0.65 \%$ & Sudan 2005 & $0.13 \%$ \\
Ethiopia & 2009 & $0.11 \%$ & Sudan 2004 & $0.40 \%$ \\
Ghana & 2009 & $0.08 \%$ & Zambia 2009 & $0.15 \%$ \\
Madagascar & 2008 & $0.23 \%$ & Zambia 2008 & $0.67 \%$ \\
Niger & 2007 & $0.38 \%$ & Zambia 2007 & $0.50 \%$ \\
Nigeria & 2009 & $0.11 \%$ & Zambia 2006 & $0.44 \%$ \\
Nigeria & 2008 & $0.13 \%$ & & & \\
Nigeria & 2007 & $0.46 \%$ & & \\
\hline
\end{tabular}

\subsection{Some Relevant Special Features of Individual Country Results}

Zambia:

Zambia had inward Chinese FDI flows which were the largest relative to GDP of any of the African countries we consider. Zambia received the second largest amount of Chinese FDI from 2003 to 2009 in absolute value (after Nigeria and with South Africa excluded), receiving US\$ 550 million. Zambia has the largest copper reserves of any country globally and it is into this sector that Chinese FDI flows are largely concentrated. Chinese FDI thus played a consistent and significant role in Zambia's GDP growth in the second half of the decade.

\section{Democratic Republic of the Congo:}

The DRC saw little Chinese FDI initially, but this picked up significantly in the second half of the decade, contributing $0.11 \%$ and $0.16 \%$ GDP growth in both 2006 and 2007 . It saw a large spike in the last year (2009) with Chinese inward FDI's contribution to GDP growth increasing to $0.65 \%$. The 2009 value comes from the fact that the DRC has a small economy compared to its size and population (by African standards) and that Chinese inward FDI was approximately US\$227 million in that year alone. The DRC is rich in minerals and natural resources, which is responsible for the increasing levels of Chinese FDI. 


\section{Nigeria:}

Excluding South Africa, Nigeria received the largest inward Chinese FDI flows during the period 2003 to 2009 US\$ 916 million. As a result, Chinese FDI contributed $0.46 \%, 0.13 \%$, and $0.11 \%$ to annual GDP growth in 2007, 2008, and 2009 respectively. It was able to have such a large effect on Nigerian GDP growth despite it being the second largest economy in Sub-Saharan Africa (at 18\% of SSA GDP) due to Nigeria's low capital stock to GDP ratio. The large capital share for Nigeria also plays a part in this.

\section{Angola:}

Angola is noteworthy not so much for the growth resulting from Chinese inward FDI, but rather the seeming lack of it. Chinese entities are heavily involved in Angola, yet Chinese inward FDI accounted for less than $0.05 \%$ GDP growth over the 2003 to 2009 period. Angola receives a large amount of aid and loans from the Chinese government, but only a small amount of Chinese FDI (over the period, it received less than Kenya or Ghana). It is unclear whether this is the result of an omission of resource exploration in the posted FDI numbers or just of China using predominantly other methods (i.e. Official Development Assistance (ODA) or Angola-Mode loans) to achieve its economic goals in Angola. The 2010 Chinese Statistical Yearbook breaks down outward Chinese FDI and there is a section for "scientific research, technical service, and geological prospecting" included in the total numbers. What may be the case is that exploration costs may be included, but the costs of the rights to operate on that land omitted. It may also be possible that the majority of posted FDI is for further resource exploration. 


\subsection{Possible Negative Effects of Chinese FDI on African Growth}

One interesting feature of the results is that in some cases, our counterfactual experiments produces slightly negative effects. ${ }^{45}$ This is not a result of the FDI having a harmful effect on growth, but reflects the mathematics behind how our experiments are carried out. We use an initial 2002 experiment which starts with a counterfactual gross capital stock in 2003. By 2008, counterfactual capital stocks have compounded over 5 to 6 years. In cases where the bulk of Chinese FDI came earlier in the 2003-2009 period, the absence of these flows compounds and produce a lower counterfactual gross capital stock for 2008-2009. As a result, for these years, the lower level of investment is more than offset by the lower levels of initial capital stock, resulting in a minor negative effect of Chinese FDI in these years. This is apparent in 2008 South Africa, where we have assumed that Chinese FDI was zero for the year and our experiment produces a slightly negative result.

\subsection{Cases of Negative FDI flows}

There are some other cases where negative Chinese FDI flows are reported in certain years. ${ }^{46}$ While in most cases, these negative flows are small, Sudan's in 2008 was US\$ -63 million (in 2007, Chinese FDI into Sudan was US\$ 65 million). We assume that this reflects a net withdrawal of Chinese FDI in the period. The result of the counterfactual growth accounting experiment showed that Sudan's growth resulting from Chinese FDI was in excess of $0.5 \%$ before 2008 , but this large withdrawal of Chinese FDI leads to a drop of $0.17 \%$ of GDP growth in 2008 .

\subsection{Excessive GDP Growth in some countries and years}

In some cases, certain African countries have recorded extremely high annual growth rates during the 2003 to 2009 period. Three countries (Angola, Ethiopia, and Sudan) had growth rates in the

\footnotetext{
${ }^{45}$ South Africa: 2008 \& 2009. Sudan: 2009

${ }^{46}$ Angola: 2008. Niger: 2008. Sudan: 2008. Tanzania: 2007.
} 
range of $10 \%$ per annum for parts of our period of analysis which it supported by World Band Development Indicators data. Nigerian GDP grew in 2004 by $34 \%$ according to data; while in its other years, it generally stayed between $5-10 \%$ per annum. Compared to the World Bank Databank, this is inconsistent, but this growth rate is what is recorded in the United Nations Main Aggregates Database. This has no effect on the effect of capital stock growth on GDP as it is absorbed entirely into the TFP growth calculation (which is calculated as a residual). As a result of this, our estimates for Chinese FDI's contribution to growth remain unaffected.

\subsection{TFP Growth}

TFP growth is different in individual countries. Some see fairly stagnant TFP growth (Botswana, Ghana, Madagascar, Tanzania), while others see consistent and strongly negative TFP growth (Sudan and Zambia). This is indicative of growth through capital accumulation as opposed to technological progress. On the other hand, Kenya and Niger experience volatile TFP growth, being positive and significant $(1+\%)$ in some years and negative and significant in others. Finally, some countries (Angola, DRC, Ethiopia and Ethiopia) have consistently high levels of TFP growth. For Angola and DRC, both of these see elevated TFP growth rates until 2009 while it drops to $-5 \%$ in Angola and $+0.5 \%$ in the DRC. This reflects the pre-financial crisis commodity boom and subsequent fall in commodity (especially oil) prices in late $2008-2009$. On a similar vein, Angola posted TFP growth rates of $15-18 \%$ for $2005-2007$ (and 8\% in 2004 and 2008) due to the steadily increasing price of oil, a significant part of Angola's domestic output. 


\section{Concluding Remarks}

China's growing commercial presence in Africa has implications for future African economic performance, quite beyond any geopolitical considerations. Here we use growth accounting methods to assess the incremental impact of Chinese inward FDI inflows to Africa, especially in the three years 2005 to 2007 before the financial crisis. These years saw both elevated growth on average in the African subcontinent, and sharp increases in Chinese FDI inflows.

Our analyses suggest that in these years while the pattern of country impact of these flows is uneven, on average there is a significant component of incremental African growth which our analyses attribute to Chinese inflows. Chinese FDI inflows were concentrated in a relatively small number of countries and in key sectors, especially in resources, and made up to $10 \%$ of total FDI inflows in certain nations' cases. There is thus diversification of impact in the destination countries for inward Chinese FDI in Sub-Saharan Africa.

Since the 2005 to 2007 period and after the 2008 Financial Crisis Chinese inflows to Africa have increased further, and the future contribution to Africa's growth will likely be larger. Combined with an equally rapidly growing, if smaller, Indian presence in Africa, the role of non OECD countries in Africa's future growth seems likely to increase. 


\section{Bibliography}

African Growth and Opportunity Act (AGOA) website: http://www.agoa.gov/agoalegislation/index.asp (accessed June 18th, 2011).

Barro, Robert J., and Jong-Wha Lee. "International comparisons of educational attainment." Journal of Monetary Economics 32 (1993), 363-394.

Berthélemy, Jean-Claude and Ludvig Söerling. "The Role of Capital Accumulation, Adjustment and Structural Change for Economic Takeoff: Empirical Evidence from African Growth Episodes." World Development 29, No.2 (2001), 323-343.

Bogetić, Željko, Maurizio Bussolo, Xiao Ye, Denis Medvedev, Quentin Wodon, and Daniel Boakye. "Ghana's growth story: How to accelerate growth and achieve MDGs." Revised Draft Paper, Ghana Country Economic Memorandum, June 2007.

Bosworth, Barry, Susan M. Collins, and Yu-Chin Chen. "Accounting for Differences in Economic Growth". Prepared for Conference on "Structural Adjustment Policies in the 1990s: Experience and Prospects", Institute of Developing Economies, Tokyo, 1995.

Bosworth, Barry and Susan M. Collins. "The Empirics of Growth: An Update." Brookings Papers on Economic Activity No.2 (2003), 113-179.

Bosworth, Barry and Susan M. Collins. "Accounting for Growth: Comparing China and India." Working Paper 12943, National Bureau of Economic Research, 2007. http://www.nber.org/papers/w12943 (accessed June 20th, 2011).

CAD Fund website - http://www.cdb.com.cn/english/Column.asp?Columnld=176 (accessed June $16^{\text {th }}$, 2011).

Crafts, Nicholas, Solow and Growth Accounting: A Perspective from Quantitative Economic History, Paper for HOPE Conference at Duke University, Durham NC, April 2008.

Dayaratna-Banda, OG and John Whalley. "After the MFA, the CCAs." Working Paper 24, The Center for International Governance Innovation, 2007.

Denison, Edward. The Sources of Economic Growth in the United States and the Alternatives Before Us. New York, NY: Committee for Economic Development, 1962.

French, Howard. "China in Africa: All Trade and No Political Baggage." New York Times, August 8, 2004.

Gollin, Douglas. “Getting Income Shares Right." Journal of Political Economy 110, No. 2 (2002), 458-474.

Hofman, André. "Capital Accumulation in Latin America: A Six Country Comparison for 1950-1989".

Review of Income and Wealth 38, No. 4 (1992), 365-401. 
Jorgenson D. W., and Z. Griliches. "An Explanation of Productivity Change." The Review of Economic Studies 34, No. 3 (1967), 249-283.

Kaplinsky, Robert and Mike Morris. "Chinese FDI in Sub Saharan Africa: Engaging With Large Dragons." European Journal of Development Research 21 (2009), 551-569.

Mail \& Guardian Online. "China Approves ICBC Stake in Standard Bank." February $4^{\text {th }}, 2008$. http://mg.co.za/article/2008-02-04-china-approves-icbc-stake-in-standard-bank (accessed June 20th, 2011).

Maddison, Angus. "Growth and Slowdown in Advanced Capitalist Economies: Techniques of Quantitative Assessment." Journal of Economic Literature 25, No. 2. (1987), 649-698.

Ministry of Commerce. People's Republic of China. Statistical Bulletin of China's Outward Foreign Direct Investment, 2010. Beijing: People's Republic of China. 2010.

Ministry of Commerce. People's Republic of China. China's Largest Commercial Bank Completes S Africa Deal. Beijing: People's Republic of China. 03/04 2008.

http://english.mofcom.gov.cn/aarticle/newsrelease/commonnews/200803/20080305410652.html (accessed July 5th, 2011).

Mohan, Giles and Marcus Power. "Africa, China and the 'new' economic geography of development." Singapore Journal of Tropical Geography, 30 (2009), 24-28.

Nehru, Vikram, and Ashok Dhareshwar. "A New Database on Physical Capital Stock: Sources, Methodology, and Results." Revista De Analisis Economico 8, No. 1 (1993), 37-59.

Njini, Felix. "Namibia: The Next Oil Frontier." Southern Times, July $8^{\text {th }}, 2011$. http://www.southerntimesafrica.com/article.php?title=Namibia\%3A_the_next_oil_frontier\&id=6097 (accessed July $9^{\text {th }}, 2011$ )

Organisation for Economic Cooperation and Development. Measuring Capital: Measurment of Capital Stocks, Consumption of Fixed Capital and Capital Services. OECD Manual. Paris: OECD, 2001.

Sacerdoti, Emilio, Sonia Brunschwig, and Jon Tang. "The Impact of Human Capital Growth: Evidence from West Africa." Working Paper 98/162, International Monetary Fund, November 1998.

Senhadji, Abdelhak. "Sources of Economics Growth: An Extensive Growth Accounting Exercise." IMF Staff Papers 47, No.1 (2000), 129-157.

Solow, Robert M. "Technical Chang and the Aggregate Production Function." The Review for Economics and Statistics 39, No.3 (1957), 312-320.

Statistical Dvision of the United Nations Secretariot. National Accounts Statistics: Main Aggregates and Detailed Tables. New York: United Nations, 2006. 
Statistical Dvision of the United Nations Secretariot. National Accounts Statistics: Main Aggregates and Detailed Tables. New York: United Nations, 2008.

UNCTADstat, United Nations Conference for Trade and Development statistical database, http://unctadstat.unctad.org/ReportFolders/reportFolders.aspx?sCS_referer=\&sCS_ChosenLang=en.

United Nations Development Programme. Asian Foreign Direct Investment in Africa. Report, 2007. http://www.unctad.org/en/docs/iteiia20071_en.pdf (accessed Nov 6th, 2010)

United Nations National Accounts Aggregates Database. http://unstats.un.org/unsd/snaama/cList.asp (accessed June 16th, 2011)

Whalley, John, and Xiliang Zhao. "The Contribution of Human Capital to China's Economic Growth." Working Paper 16592, National Bureau of Economic Research, December 2010. http://www.nber.org/papers/w16592 (accessed June $22^{\text {nd }}, 2011$ )

World Bank Development Indicators, http://data.worldbank.org/indicator.

Yan, Wang, and Yudong Yao. "Sources of China's Economic Growth 1952-1999: Incorporating Human Capital Accumulation." China Economic Review 14 (2003) 32-52.

Zhou Yan. "CAD Fund to boost footprint in Africa." China Daily. May $28^{\text {th }}, 2010$.

http://www.chinadaily.com.cn/bizchina/2010-05/28/content_9903203.htm (accessed November $8^{\text {th }}$, 2010). 